\title{
A one-step synthesis of pyrazolone
}

\section{Gernot A. Eller* and Wolfgang Holzer}

Department of Drug Synthesis, University of Vienna,

Althanstrasse 14, 1090 Vienna, Austria

Phone: +43-1-4277-55634, e-mail: gernot.eller@univie.ac.at

*Author to whom correspondence should be addressed

\section{Received: 3 January 2006 / Accepted: 4 January 2006 / Published: 22 January 2006}

Keywords: Pyrazolone, cyclization, NMR spectroscopy, tautomerism.

\begin{abstract}
The fully unsubstituted pyrazolone (= 2-pyrazolin-5-one, which is tautomer to $1 H$-pyrazol-3-ol and $1 H$-pyrazol-5-ol) was prepared from hydrazine hydrate and methyl (2E)-3methoxyacrylate in almost quantitative yield. Detailed spectroscopic data $\left({ }^{1} \mathrm{H} \mathrm{NMR},{ }^{13} \mathrm{C}\right.$ NMR, ${ }^{15} \mathrm{~N}$ NMR, MS) for this compound are presented.
\end{abstract}

Substituted 2-pyrazolin-5-ones play an important role as substructures of numerous pharmaceuticals, agrochemicals, dyes, pigments, as well as chelating agents and thus attract remarkable attention [1,2].

Recently, we investigated the synthesis of some N1-unsubstituted pyrazolones by use of the PMB ( $p$-methoxybenzyl) protecting group $[3,4]$. Although this substituent proved to be conveniently removable from various 4-substituted pyrazolones upon treatment with refluxing trifluoroacetic acid only poor results were obtained when the parent 1-PMB-pyrazolone (= 2-(4-methoxybenzyl)-2,4-dihydro-

$3 H$-pyrazol-3-one [3]) was subjected to these conditions. Even prolonged heating ( 1 week instead of 1 day) did not effect full deprotection ( 1 day $\sim 15 \%, 2$ days $\sim 35 \%, 7$ days $\sim 75 \%$; monitored by mean of ${ }^{1}$ H NMR). Hence, there is need for other and more suitable methods for the synthesis of the unsubstituted pyrazolone 1 .

With respect to the fact that other hitherto described syntheses of 1 are characterized by multi-step procedures and/or low yields [5,6], we report here an almost quantitative one-step preparation of the fully unsubstituted pyrazolone system from hydrazine hydrate and methyl (2E)-3-methoxyacrylate following an already known procedure for the synthesis of 1-alkyl pyrazolones [7] (Scheme 1).

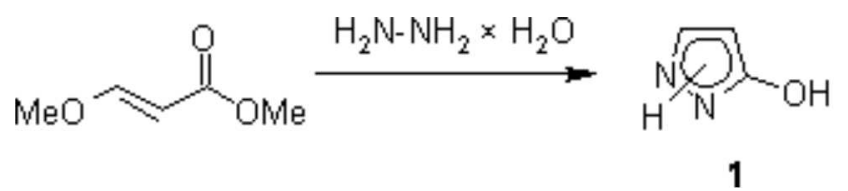

\section{Scheme 1. One-step procedure for the preparation of 'pyrazolone' 1.}

A considerable number of studies deal with the prototropic tautomerism of pyrazolones [8].

Determination of the tautomeric composition of compound $\mathbf{1}$ is quite challenging as eight possible tautomeric forms have to be considered. This may also be a reason why in the Chemical Abstracts Service (CAS) references are cited for all possible tautomeric forms of compound $\mathbf{1}$ (Figure 1) except for form $\mathbf{E}$. From the signal multiplicities in the carbon NMR spectra tautomeric forms $\mathbf{B}, \mathbf{C}, \mathbf{F}, \mathbf{G}$, and $\mathbf{H}$ can be excluded. Moreover, the ${ }^{15} \mathrm{~N}$ NMR chemical shifts found for compound $\mathbf{1}$ (-126.5 ppm and $\left.-192.0 \mathrm{ppm}\right)$ rule out form $\mathbf{A}$, as for this tautomer a much smaller chemical shift for the $=\mathrm{CH}-\mathrm{NH}-$ atom has to be expected (for instance, in phenazone - 1,5-dimethyl-2-phenyl-1,2-dihydro-3 $H$-pyrazol-3-one - which is structurally related to form A this atom exhibits a chemical shift of $-245.1 \mathrm{ppm}$ [9]). The differentiation 
between forms $\mathbf{D}$ and $\mathbf{E}$ is not a trivial task. However, from comparison of the ${ }^{13} \mathrm{C}$ chemical shifts, the ${ }^{15} \mathrm{~N}$ chemical shifts, the ${ }^{3} J(\mathrm{H}, \mathrm{H})$ coupling constants, and the different ${ }^{13} \mathrm{C},{ }^{1} \mathrm{H}$-coupling constants of 1 with those of the corresponding $\mathrm{N}$-phenyl analogues (1-phenyl-1H-pyrazol-3-ol, 1-phenyl-1H-pyrazol-5-ol) $[10,11]$ we assume that form $\mathbf{D}$ is predominating in DMSO- $d_{6}$ solution. Nevertheless an additional contribution of other isomers (in minor amounts) can not be ruled out.<smiles></smiles>

A<smiles>Oc1ccn[nH]1</smiles>

$\mathrm{E}$<smiles>O=C1CC=NN1</smiles>

B<smiles>OC1C=CN=N1</smiles>

$\mathbf{F}$<smiles>O=C1CCNN1</smiles>

C<smiles>OC1=NN=CC1</smiles>

G<smiles>Oc1cc[nH]n1</smiles>

D<smiles>OC1=CCN=N1</smiles>

H

Figure 1. Possible tautomeric forms of 'pyrazolone' 1.

Compound 1: Under stirring, to a solution of $5.81 \mathrm{~g}(50 \mathrm{mmol})$ of methyl $(2 E)-3$-methoxyacrylate in methanol $(5 \mathrm{~mL})$ was hydrazine hydrate $(2.75 \mathrm{~g}, 55 \mathrm{mmol})$ added and the mixture was refluxed for $1 \mathrm{~h}$. Evaporation under reduced pressure to dryness gave $4.13 \mathrm{~g}(98 \%)$ of a slightly yellowish powder, pure according to ${ }^{1} \mathrm{H}$ NMR spectroscopy.

Melting point: $160-162{ }^{\circ} \mathrm{C}$, crystal modifications starting at $\sim 140{ }^{\circ} \mathrm{C}$, (lit. [12] $162-164{ }^{\circ} \mathrm{C}$ ).

${ }^{1} \mathrm{H}-\mathrm{NMR}\left(300 \mathrm{MHz}, \mathrm{DMSO}-d_{6}, 28^{\circ} \mathrm{C}\right.$, numbering for $1 H$-pyrazol-3-ol = form D) [13]: $\delta=9.82(\mathrm{br} \mathrm{s}, 2 \mathrm{H}$, $\mathrm{XH}) ; 7.33\left(\mathrm{~d},{ }^{3} J_{(\mathrm{H} 5, \mathrm{H} 4)}=2.3 \mathrm{~Hz}, 1 \mathrm{H}, \mathrm{H} 5\right) ; 5.43\left(\mathrm{~d},{ }^{3} J_{(\mathrm{H} 4, \mathrm{H} 5)}=2.3 \mathrm{~Hz}, 1 \mathrm{H}, \mathrm{H} 4\right)$.

${ }^{13} \mathrm{C}-\mathrm{NMR}\left(75 \mathrm{MHz}\right.$, DMSO- $d_{6}, 28{ }^{\circ} \mathrm{C}$, numbering for $1 H$-pyrazol-3-ol $=$ form $\left.\mathbf{D}\right)[13]: \delta=161.0(\mathrm{C} 3$, $\left.{ }^{2} J_{(\mathrm{C} 3, \mathrm{H} 4)}=3.4 \mathrm{~Hz},{ }^{3} J_{(\mathrm{C} 3, \mathrm{H} 5)}=9.2 \mathrm{~Hz}\right) ; 130.1\left(\mathrm{C} 5,{ }^{1} \mathrm{~J}=184.0 \mathrm{~Hz},{ }^{2} J_{(\mathrm{C} 5, \mathrm{H} 4)}=8.2 \mathrm{~Hz}\right) ; 89.3\left(\mathrm{C} 4,{ }^{1} J=175.6\right.$ $\left.\mathrm{Hz},{ }^{2} J_{(\mathrm{C} 4, \mathrm{H} 5)}=8.7 \mathrm{~Hz}\right)$.

${ }^{15}$ N-NMR (50 MHz, DMSO-d6, 294 K) [14]: $\delta=-126.5 ;-192.0$.

$\operatorname{MS}(\mathrm{m} / \mathrm{z}, \%)[15]: 84\left(\mathrm{M}^{+}, 100\right) ; 55(24)$.

Elemental Analysis: Calculated for $\mathrm{C}_{3} \mathrm{H}_{4} \mathrm{~N}_{2} \mathrm{O}$ (84.08): C, 42.86\%; H, 4.80\%; N, 33.32\%. Found: C, $42.75 \%$; H, 4.65\%; N, 33.15\%.

\section{References and Notes:}

1. J. Elguero, In 'Comprehensive Heterocyclic Chemistry: Pyrazoles and their Benzo Derivatives', Vol. 5; A. R. Katritzky and C. W. Rees, Eds., Pergamon Press, Oxford, 1984, 167-303.

2. Stanovnik, B.; Svete, J. Product class 1: Pyrazoles. Science of Synthesis 2002, 12, 15-225.

3. Eller, G. A.; Holzer, W. Heterocycles 2004, 63, 2537-2555.

4. Becker, W.; Eller, G. A.; Holzer, W. Synthesis 2005, 2583-2589.

5. Testa, E.; Fontanella, L. Farmaco 1971, 26, 1017-35.

6. Dorn, H.; Zubek, A. J. Prakt. Chem. 1971, 313, 1118-24.

7. Maywald, V.; Steinmetz, A.; Rack, M.; Gotz, N.; Gotz, R.; Henkelmann, J.; Becker, H.; Aiscar Bayeto, PCT Int. Appl. WO 0031042 A2 2000 (Chem. Abstr., 2000, 133, 4655).

8. Holzer, W.; Hallak, L. Heterocycles 2004, 63, 1311-1334, and references cited therein.

9. Cizmarik, J.; Lycka, A. Pharmazie 1988, 43, 794-795.

10. Holzer, W.; Kautsch, C.; Laggner, C.; Claramunt, R. M.; Perez-Torralba, M.; Alkorta, I.; Elguero, J. 
Tetrahedron 2004, 60, 6791-6805.

11. Sackus, A.; Holzer, W. manuscript in preparation.

12. Lingens, F.; Schneider-Bernloehr, H. Liebigs Ann. Chem. 1965, 686, 134-144.

13. The spectrum was obtained on a Varian UnityPlus 300 spectrometer $\left(299.95 \mathrm{MHz}\right.$ for ${ }^{1} \mathrm{H}, 75.43 \mathrm{MHz}$ for ${ }^{13} \mathrm{C}$ ). The center of the solvent signal was used as an internal standard which was related to TMS with $\delta 2.49 \mathrm{ppm}\left({ }^{1} \mathrm{H} \mathrm{NMR}\right)$ and $\delta 39.5 \mathrm{ppm}\left({ }^{13} \mathrm{C}\right.$ NMR $)$.

14. The spectrum was obtained on a Bruker Avance 500 spectrometer and was referenced against neat, external nitromethane (coaxial capillary). The signals were not unequivocally assigned to the $\mathrm{N}$ atoms.

15. The spectrum was obtained on a Shimadzu QP 1000 instrument (EI, 70eV).

Sample Availability: Available from MDPI.

(C) 2006 MDPI. All rights reserved. 